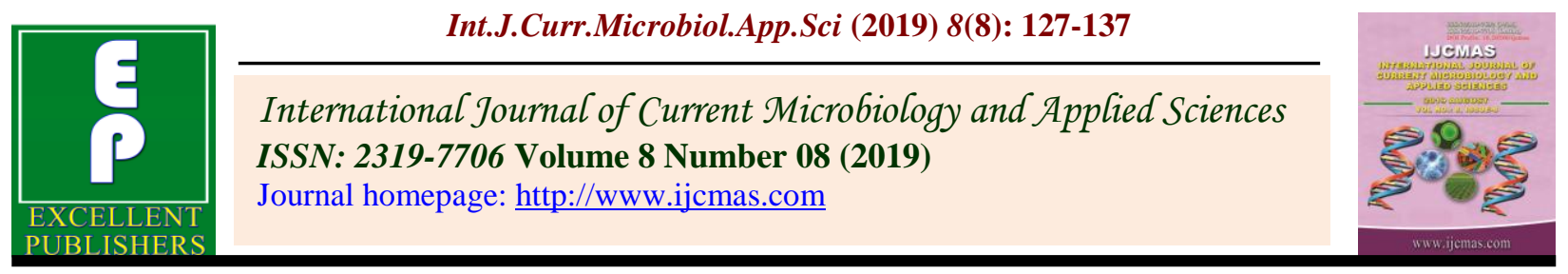

Original Research Article

https://doi.org/10.20546/ijcmas.2019.808.016

\title{
Effect of Fly Ash on Growth and Yield of Crops with Special Emphasis on Heavy Metals and Radionuclide's
}

\author{
G.R. Rajakumar ${ }^{1}$ and S.V. Patil ${ }^{2 *}$ \\ ${ }^{1}$ Regional Agricultural Research Station, Hitnalli Farm, Vijayapur-586 101, India \\ ${ }^{2}$ College of Horticulture, Department of Natural Resource Managaement, UHS Campus, \\ GKVK, Bengaluru -560 065, India \\ *Corresponding author
}

\begin{tabular}{|l|}
\hline Ke y w o r d s \\
Fly ash (FA), Pond \\
Ash (PA), \\
Sunflower \\
\hline Article Info \\
\hline $\begin{array}{l}\text { Accepted: } \\
\text { 04 July 2019 } \\
\text { Available Online: } \\
\text { 10 August } 2019\end{array}$ \\
\hline
\end{tabular}

A B S T R A C T

Safe disposal of the coal ashes is the major concern now. Looking to its potentiality, coal ash can be utilized in agriculture field crops for applications as an amendment of soil properties and nutrient supply. The properties of Fly ash (FA) and Pond ash (PA) indicated that these are having good water holding capacity and have more of sand and silt particles. The use of FA and Pond ash PA along with or without FYM in sunflower crop enhanced growth and yield parameters. The germination of seeds is also influenced greatly by these ashes. The sunflower plant height varied more significantly due to FA and PA application in black soil, however it is less significant in red soils. Application of ashes at the rate of 30 t/ha along with FYM in both red soil and black soil resulted in significantly higher head diameter and test weight in turn seed yield and oil content.

\section{Introduction}

The thermal power units are mainly based on coal which is used for the fuel purpose. After burning of the coal huge amount of ash will be generated. The finer ash (flyash) material will be separated from slightly coarser ash. Handling and disposal of the ash produced is a big task (Manish et al., 2008). The ash is known to contain some trace elements, heavy metals and radionuclide's which is a potential hazardous waste (Sikka and Kansal, 1974).
The high ash content (30-50\%) of the coal in India makes this problem complex. Safe disposal of the ash without adversely affecting the environment and the large storage area required for dumping are the major concerns. Hence attempts are being made to utilize the ash rather than dumping it. The coal ash can be utilized in agriculture field crops for improving soil properties and nutrient supply. In this context an in-depth understanding of the influence of fly ash on growth and yield of crops is required. This paper reports the work 
carried out by research scholars in this context at the Department of Soil Science, UAS Raichur. The types of ashes available at Racihur Thermal Power station (RTPS) are the Fly ash which is finer and the other is the Pond ash which is stored in a big pond at the site adjacent to Yarmarus village in Raichurtaluk which is dumped here after mixing the fresh coarse ash with water and carried through pipes and channels. The huge amount of ash coming out from the industry is needed to utilize in various field fields.

The research work carried out at the Department of Soil Science, UAS Raichur has come out with package to utilize it in the field of agriculture. The scholar research carried out on use of Fly ash (FA) and Pond ash (PA) in sunflower crop are delineated here.

\section{Materials and Methods}

Ash samples were drawn from the industry plant (FA) and pond (PA) from RTPS and applied to field @ 30 and 40 tons per hectare with and without FYM as per the treatments during kharif season. Incorporation of the ashes were done using tractor after manual spreading. The initial soil samples, FYM, Flyash and Pondash were characterized in the laboratory (Table 1). The analysis for physicochemical properties and heavy metal content was carried out at Department of Soil Science, College of Agriculture, Raichur. And the measurement of activity level of radionuclides was carried out at Institute of Physics, Bhuvaneshwar. The plant analysis at harvest of crop, during each season (kharif / rabi) was carried out for two years and the influence of ashes on uptake of heavy metals by sunflower (during kharif in both red and black soil), groundnut (during rabi in red soil) and maize (during rabi in black soil) crops was recorded and radionuclides were assessed through their radioactivity measurement (Papastefanou, 2008).

\section{Results and Discussion}

Characteristics of soils, fly ash, pond ash and FYM

The characteristics of samples are presented in table 1. The texture of red soil (Alfisol) is sandy clay loam and its maximum water holding capacity is 41 per cent. Water Holding Capacity (WHC) of flyash is generally 49$66 \%$ on weight basis, while the moisture retention ranges from $6.1 \%$ at 15 bar to $13.4 \%$ at $1 / 3$ bar (Natusch and Wallace, 1974). The soil is alkaline, non-saline with medium organic carbon content. Available N status is low and available $\mathrm{P}$ and $\mathrm{K}$ status is medium. The texture of black soil (Vertisol) is clayey and the maximum water holding capacity is 64 per cent. The soil is alkaline and medium in available $\mathrm{N}$ and the available $\mathrm{K}$ status of soil is high.

The properties of Fly ash (FA) and Pond ash (PA) indicated that the particles present in FA were finer than PA. The texture of FA was silt clay loam and that of PA was silt loam. These two properties make the soil friable and favour plant growth when applied. Coal ashes were predominantly silt sized with some sand-size fraction. Fly-ash particles are empty spheres (cenospheres) filled with smaller amorphous particles and crystals (plerospheres) (Manish pande et al., 2008). The moisture holding capacity is also higher with PA $(68 \%)$ than FA $(50 \%)$. And these are having good water holding capacity and have more of sand and silt particles. The $\mathrm{pH}$ of ashes were strongly alkaline (9.3 to 10.5), among the two, FA was having more. The EC of the ashes is <1.0 $\mathrm{dS} / \mathrm{m}$ among the two, FA is having more. These were found to be good sources of potash, calcium, magnesium, sulphur and micronutrients. The DTPA extractable micronutrients in fly ash and pond ash are quite good which can contribute more amounts when applied in tons. The total NPK 
contents ( 0.007 to $0.015,0.2$ to 0.4 and 1.1 to $1.8 \%$ respectively) and the plant available NPK contents in these ashes are very low (20 to 40,10 to 16 and 94 to $145 \mathrm{ppm}$, respectively). The total content of calcium in these ashes is 2.5 to 3.6 percent, however the ammonium acetate extractable calcium is very low (9 to $16 \mathrm{Cmol} / \mathrm{kg}$ ). The total content of magnesium in these ashes is 1.2 to $1.7 \%$, however the ammonium acetate extractable magnesium is also very low (2 to 13 $\mathrm{Cmol} / \mathrm{kg}$ ). The total sulphur in ashes is varied between 1.4 and 2.5 percent and plant available sulphur is varied between 45 and 78 ppm. The plant available micronutrients $\mathrm{Cu}$, $\mathrm{Fe}, \mathrm{Mn}$ and $\mathrm{Zn}$ are in the range of 0.3 to 0.6 , 8.6 to $12.5,8$ to 13 and 1.0 to 1.5 , respectively. These results indicate the potential source of ashes which can be exploited to utilize in agricultural fields (Patil et al., 1999). Theis and Wirth (1977) found that the major components were $\mathrm{Al}, \mathrm{Fe}$ and $\mathrm{Si}$, with smaller concentrations of $\mathrm{Ca}, \mathrm{K}, \mathrm{Na}, \mathrm{Ti}$, and S. Fly-ash contains varying amounts of numerous trace elements, some of which are required by plant and animals in varying amounts (Martens, 1971), whereas some may have toxic effect. Fly-ash contains essential macronutrients including $\mathrm{P}, \mathrm{K}, \mathrm{Ca}, \mathrm{Mg}$ and $\mathrm{S}$ and micronutrients like $\mathrm{Fe}, \mathrm{Mn}$ and $\mathrm{Zn}$. Agricultural utilization of fly ash has been proposed because of its considerable content of K, Ca and S (Kalra et al., 1997; Singh et al., 1997).

The heavy metal content of FA varied more than that of PA. Davison et al., (1974) indicated that the trace elements concentration in fly ash: depends on particle size. The level of radio activity in both ashes was not significant but doubles the soils. The FYM also showed appreciable moisture holding capacity than soils and ashes. The $\mathrm{pH}$ was near neutral and did contain good amounts of plant available nutrients. The heavy metal contents and activity of radionuclides was lower and similar to soil.

\section{Influence of application of FA and PA on growth and yield of crops}

The application of FA and PA to sunflower crop in kharif season of both the years before sowing in red soil and black soil at the rate of 30 and 40 t/ha resulted in significant variations in growth and yield sunflower and subsequent rabi crops groundnut in red soil and maize in black soil (Table 2).

The germination of seeds is also influenced greatly by these ashes. In red soil it is 90 percent in control and 96 percent in PA and FA applied plots when used along with FYM. Treating the red soils by fly ash alone resulted $4 \%$ higher germination than control indicating the necessity of ash application. In black soil it was not much influenced.

Treating the black soils with ash alone resulted in on-par germination as that of control than with FYM indicating the essentiality of inclusion of organics with ash application (Shukla and Mishra, 1986 and Yeldhalli, 2007) (Table 3-7).

\section{Plant height of sunflower and maize}

The plant height crops varied more significantly due to FA and PA application in black soil, however it is less significant in red soils. In sunflower it was $151 \mathrm{~cm}$ in control which increased to 180 and $182 \mathrm{cms}$ in FA and PA applied plots in red soil, while it was 151 $\mathrm{cm}$ in control which increased to 180 and 182 $\mathrm{cms}$ in FA and PA applied plots in black soil. In maize grown on black soil during rabi season of both years, it was $151 \mathrm{~cm}$ in control which increased to 180 and $182 \mathrm{cms}$ in FA and PA along with FYM applied plots in black soil. This indicated the influence of ashes is very prominent on making soil friable and loose for roots water to penetrate in to the soil deeply (Shukla and Mishra, 1986 and Yeldhalli, 2007). 
Table.1 Characteristics of soils, ashes and FYM

\begin{tabular}{|c|c|c|c|c|c|c|}
\hline $\begin{array}{l}\text { SI. } \\
\text { No. }\end{array}$ & Parameter & Red soil & Black soil & Fly ash & Pond ash & FYM \\
\hline 1. & Texture & Sandy Clay & Clay & Silt clay loam & Silt loam & - \\
\hline \multicolumn{7}{|c|}{ Moisture holding capacity } \\
\hline 2. & MWHC \% & 41.9 & 64.2 & 50.2 & 68.1 & 155 \\
\hline 3. & FC \% & 23.2 & 36.7 & 24.2 & 38.0 & 82.0 \\
\hline 4. & PWP \% & 9.1 & 16.4 & 5.6 & 11.0 & 17.8 \\
\hline \multicolumn{7}{|c|}{ Chemical properties } \\
\hline 5. & $\mathrm{pH}$ & 8.50 & 8.60 & 9.82 & 8.99 & 7.7 \\
\hline 6. & $\mathrm{EC}, \mathrm{dS} / \mathrm{m}$ & 0.10 & 0.10 & 0.87 & 0.34 & 0.6 \\
\hline 7. & Organic C $(\%)$ & 0.60 & 0.90 & - & - & - \\
\hline \multicolumn{7}{|c|}{ Nutrient Content } \\
\hline 8. & Total N \% & 0.07 & 0.09 & 0.007 & 0.015 & 1.24 \\
\hline 9. & Available N & $206 \mathrm{~kg} / \mathrm{ha}$ & 306 kg/ha & $30.2 \mathrm{ppm}$ & $39.6 \mathrm{ppm}$ & $355 \mathrm{ppm}$ \\
\hline 10. & Total P \% & 0.06 & 0.08 & 0.43 & 0.42 & 0.80 \\
\hline 11. & Available P2O5 & $33.9 \mathrm{~kg} / \mathrm{ha}$ & $19.2 \mathrm{~kg} / \mathrm{ha}$ & $16.7 \mathrm{ppm}$ & $11.6 \mathrm{ppm}$ & $890 \mathrm{ppm}$ \\
\hline 12. & Total K \% & 1.20 & 1.65 & 1.8 & 1.6 & 1.10 \\
\hline 13. & Available $\mathrm{K} 2 \mathrm{O}$ & $292 \mathrm{~kg} / \mathrm{ha}$ & $770 \mathrm{~kg} / \mathrm{ha}$ & $145.2 \mathrm{ppm}$ & $101.2 \mathrm{ppm}$ & $1126 \mathrm{ppm}$ \\
\hline 14. & Total Ca \% & 0.52 & 1.30 & 3.36 & 2.66 & 1.00 \\
\hline 15. & Exch.Ca $(\mathrm{Cmol} / \mathrm{kg})$ & 14.5 & 39.7 & 19.2 & 10.1 & - \\
\hline 16. & Total Mg \% & 0.30 & 0.78 & 1.19 & 1.53 & 0.14 \\
\hline 17. & Exch.Mg $(\mathrm{Cmol} / \mathrm{kg})$ & 1.4 & 12.1 & 13.4 & 5.0 & - \\
\hline 18. & Total S \% & 0.03 & 0.06 & 2.50 & 1.75 & 0.36 \\
\hline 19. & Available SO4-S & 13.9 & 38.7 & 78.2 & 51.2 & 15.3 \\
\hline 20. & Total $\mathrm{Cu}, \mathrm{ppm}$ & 32.5 & 40.0 & 100 & 80 & 40 \\
\hline 21. & DTPA Extr-Cu, ppm & 2.60 & 1.59 & 0.62 & 0.44 & 2.1 \\
\hline 22. & Total Fe, \% & 1.46 & 2.16 & 2.00 & 2.59 & 1.13 \\
\hline 23. & DTPA Extr-Fe, ppm & 4.41 & 2.17 & 12.50 & 12.46 & 26.2 \\
\hline 24. & Total Mn, ppm & 315 & 390 & 270 & 380 & 300 \\
\hline 25. & DTPA Extr-Mn, ppm & 9.1 & 8.1 & 12.17 & 3.00 & 11.2 \\
\hline 26. & Total Zn, ppm & 43 & 50 & 170 & 70 & 31.0 \\
\hline \multicolumn{7}{|c|}{ Heavy metals (mg/kg) } \\
\hline 27. & Total Se & 1.20 & 0.90 & 1.60 & 1.90 & 0.50 \\
\hline 28. & Available Se & BDL & BDL & BDL & BDL & BDL \\
\hline 29. & Total As & 1.40 & 1.20 & 2.3 & 20.2 & 0.80 \\
\hline 30. & Available As & BDL & BDL & BDL & BDL & BDL \\
\hline 31. & Total $\mathrm{Pb}$ & 14.8 & 19.9 & 18.4 & 20.2 & 7.9 \\
\hline 32. & Available $\mathrm{Pb}$ & 0.03 & 0.18 & 0.03 & 0.03 & 0.06 \\
\hline \multicolumn{7}{|c|}{ Activity of Radionuclides $(\mathrm{Bq} / \mathrm{kg})$} \\
\hline 33. & Alpha & 161.7 & 126.5 & 236.6 & 210.8 & 115.2 \\
\hline 34. & Beta & 32.4 & 318.0 & 623.1 & 609.5 & 141.0 \\
\hline 35. & ${ }^{40} \mathrm{~K}$ Gamma & 291.3 & 282.3 & 359.3 & 353.7 & 136.6 \\
\hline 36. & ${ }^{226} \mathrm{Ra}$ Gamma & 38.5 & 37.5 & 99.7 & 91.8 & 16.6 \\
\hline 37. & ${ }^{228} \mathrm{Ac}$ Gamma & 60.1 & 65.9 & 108.2 & 106.2 & 24.4 \\
\hline
\end{tabular}


Table.2 Influence of FA and PA with and without FYM on growth and yield parameters of sunflower (average of first year kharif and second year kharif)

\begin{tabular}{|c|c|c|c|c|c|c|c|c|c|c|c|c|}
\hline \multirow[t]{2}{*}{ Treatment } & \multicolumn{6}{|c|}{ In Red Soil } & \multicolumn{6}{|c|}{ In Black soil } \\
\hline & $\begin{array}{c}\text { Germin } \\
\text { ation } \\
(\%)\end{array}$ & $\begin{array}{l}\text { Plant } \\
\text { height } \\
(\mathrm{cm})\end{array}$ & $\begin{array}{c}\text { Head } \\
\text { diameter } \\
(\mathrm{cm})\end{array}$ & $\begin{array}{c}\text { Test } \\
\text { weight } \\
\text { (g) }\end{array}$ & $\begin{array}{l}\text { Seed } \\
\text { yield } \\
\text { (q/ha) }\end{array}$ & $\begin{array}{c}\text { Oil } \\
\text { content } \\
(\%)\end{array}$ & $\begin{array}{c}\text { Germin } \\
\text { ation } \\
(\%)\end{array}$ & $\begin{array}{c}\text { Plant } \\
\text { height } \\
\text { (cm) }\end{array}$ & $\begin{array}{c}\text { Head } \\
\text { diameter } \\
(\mathrm{cm})\end{array}$ & $\begin{array}{c}\text { Test } \\
\text { weight } \\
\text { (g) }\end{array}$ & $\begin{array}{r}\text { Seed } \\
\text { yield } \\
(\mathrm{q} / \mathrm{ha})\end{array}$ & $\begin{array}{c}\text { Oil } \\
\text { content } \\
(\%)\end{array}$ \\
\hline $\begin{array}{l}\text { T1-Control } \\
\text { (Only NPK) }\end{array}$ & 90 & 171 & 12.0 & 41.5 & 7.7 & 31.6 & 94 & 151 & 11.8 & 41.9 & 8.8 & 30.7 \\
\hline $\begin{array}{l}\text { T2-FA@30 } \\
\text { t/ha }\end{array}$ & 95 & 180 & 13.1 & 44.6 & 9.6 & 33.3 & 95 & 170 & 13.0 & 46.6 & 10.0 & 31.6 \\
\hline $\begin{array}{l}\text { T3-FA@40 } \\
\text { t/ha+FYM }\end{array}$ & 96 & 190 & 14.7 & 46.9 & 10.5 & 33.8 & 96 & 180 & 14.0 & 52.3 & 11.4 & 33.4 \\
\hline $\begin{array}{l}\text { T4-FA@40 } \\
\text { t/ha }\end{array}$ & 95 & 184 & 13.2 & 47.4 & 10.2 & 33.8 & 94 & 173 & 13.9 & 46.6 & 10.8 & 32.1 \\
\hline $\begin{array}{l}\text { T5-FA@30 } \\
\text { t/ha only once }\end{array}$ & 94 & 179 & 13.6 & 45.4 & 9.7 & 33.6 & 95 & 169 & 13.3 & 48.5 & 10.0 & 31.5 \\
\hline $\begin{array}{l}\text { T6- PA@30 } \\
\text { t/ha }\end{array}$ & 95 & 185 & 13.7 & 45.3 & 8.7 & 32.1 & 95 & 178 & 13.5 & 46.5 & 10.7 & 32.1 \\
\hline $\begin{array}{l}\text { T7-PA@40 } \\
\text { t/ha+FYM }\end{array}$ & 96 & 191 & 14.8 & 48.6 & 10.1 & 34.5 & 96 & 182 & 15.6 & 50.0 & 11.3 & 33.1 \\
\hline $\begin{array}{l}\text { T8-PA@40 } \\
\text { t/ha }\end{array}$ & 94 & 182 & 13.7 & 45.2 & 9.8 & 33.6 & 95 & 171 & 13.8 & 49.8 & 10.1 & 32.5 \\
\hline $\begin{array}{l}\text { T9- PA@30 } \\
\text { t/ha only once }\end{array}$ & 94 & 183 & 14.1 & 44.5 & 9.6 & 32.4 & 95 & 179 & 13.2 & 47.0 & 10.2 & 32.2 \\
\hline SEm+/- & 0.33 & 1.63 & 0.19 & 0.74 & 0.3 & 0.58 & 0.66 & 2.35 & 0.23 & 0.56 & 0.22 & 1.21 \\
\hline D at $5 \%$ & 0.98 & 5.78 & 0.57 & 2.21 & 0.88 & 1.73 & 1.98 & 7.04 & 0.68 & 1.67 & 0.67 & 3.61 \\
\hline
\end{tabular}


Table.3 Influence of FA and PA with and without FYM on growth and yield parameters (average of first year rabi and second year rabi)

\begin{tabular}{|c|c|c|c|c|c|c|c|c|c|c|c|c|}
\hline \multirow[t]{2}{*}{ Treatment } & \multicolumn{6}{|c|}{ Groundnut in Red Soil } & \multicolumn{6}{|c|}{ Maize in Black soil } \\
\hline & $\begin{array}{c}\text { Germin } \\
\text { ation } \\
(\%)\end{array}$ & $\begin{array}{l}\text { No.of } \\
\text { pods / } \\
\text { plant }\end{array}$ & $\begin{array}{c}\text { Sheiling } \\
\%\end{array}$ & $\begin{array}{c}\text { Test } \\
\text { weight } \\
\text { (g) }\end{array}$ & $\begin{array}{c}\text { Pod } \\
\text { yield } \\
\text { (q/ha) }\end{array}$ & $\begin{array}{c}\text { Oil } \\
\text { content } \\
(\%)\end{array}$ & $\begin{array}{c}\text { Germin } \\
\text { ation } \\
(\%)\end{array}$ & $\begin{array}{c}\text { Plant } \\
\text { height } \\
(\mathrm{cm})\end{array}$ & $\begin{array}{c}\text { Cob } \\
\text { length } \\
(\mathrm{cm})\end{array}$ & $\begin{array}{c}\text { Test } \\
\text { weight } \\
\text { (g) }\end{array}$ & $\begin{array}{c}\text { Seed } \\
\text { yield } \\
\text { (q/ha) }\end{array}$ & $\begin{array}{c}\text { Stover } \\
\text { yield } \\
\text { (t/ha) }\end{array}$ \\
\hline $\begin{array}{l}\text { T1-Control } \\
\text { (Only NPK) }\end{array}$ & 80.47 & 10.15 & 65.72 & 238.80 & 10.32 & 45.67 & 80.44 & 117.5 & 13.03 & 231.47 & 17.70 & 26.46 \\
\hline $\begin{array}{l}\text { T2-FA@30 } \\
\text { t/ha }\end{array}$ & 90.07 & 11.45 & 69.69 & 268.10 & 14.96 & 45.83 & 87.94 & 127.85 & 15.07 & 237.80 & 20.84 & 30.80 \\
\hline $\begin{array}{l}\text { T3-FA@40 } \\
\text { t/ha+FYM }\end{array}$ & 94.07 & 14.00 & 71.42 & 276.80 & 17.11 & 46.44 & 93.10 & 148.12 & 16.00 & 238.87 & 22.41 & 32.79 \\
\hline $\begin{array}{l}\text { T4- FA@40 } \\
\text { t/ha }\end{array}$ & 92.57 & 12.05 & 70.04 & 270.60 & 15.02 & 45.77 & 84.62 & 144.45 & 15.77 & 238.07 & 21.13 & 29.80 \\
\hline $\begin{array}{l}\text { T5-FA@30 } \\
\text { t/ha only once }\end{array}$ & 88.00 & 11.14 & 67.66 & 270.90 & 13.88 & 45.88 & 88.07 & 127.43 & 14.43 & 238.50 & 20.50 & 25.12 \\
\hline $\begin{array}{l}\text { T6-PA@30 } \\
\text { t/ha }\end{array}$ & 89.56 & 11.52 & 66.93 & 275.90 & 16.26 & 45.80 & 87.92 & 140.44 & 14.07 & 239.07 & 21.17 & 30.80 \\
\hline $\begin{array}{l}\text { T7-PA@40 } \\
\text { t/ha+FYM }\end{array}$ & 90.23 & 12.70 & 70.87 & 293.60 & 17.78 & 46.37 & 96.19 & 149.77 & 16.98 & 239.33 & 22.56 & 34.88 \\
\hline $\begin{array}{l}\text { T8- PA@40 } \\
\text { t/ha }\end{array}$ & 85.47 & 12.18 & 69.11 & 271.70 & 14.89 & 46.30 & 89.24 & 142.27 & 14.25 & 237.67 & 21.94 & 30.98 \\
\hline $\begin{array}{l}\text { T9- PA@ } 30 \\
\text { t/ha only once }\end{array}$ & 87.37 & 11.43 & 69.32 & 269.30 & 13.70 & 45.63 & 87.97 & 136.68 & 14.45 & 238.53 & 21.75 & 28.68 \\
\hline SEm+/- & 0.594 & 0.30 & 0.79 & 4.64 & 0.43 & 0.32 & 0.653 & 3.57 & 0.39 & 1.04 & 0.72 & 1.63 \\
\hline D at $5 \%$ & 1.780 & 0.89 & 2.36 & 13.91 & 1.28 & 0.53 & 1.957 & 10.70 & 1.17 & 3.10 & 1.26 & 4.88 \\
\hline
\end{tabular}


Table.4 Influence of application of FA and PA with and without FYM to sunflower on micronutrients, heavy metals and radio nuclides uptake by sunflower in Red soil during kharif (two years average)

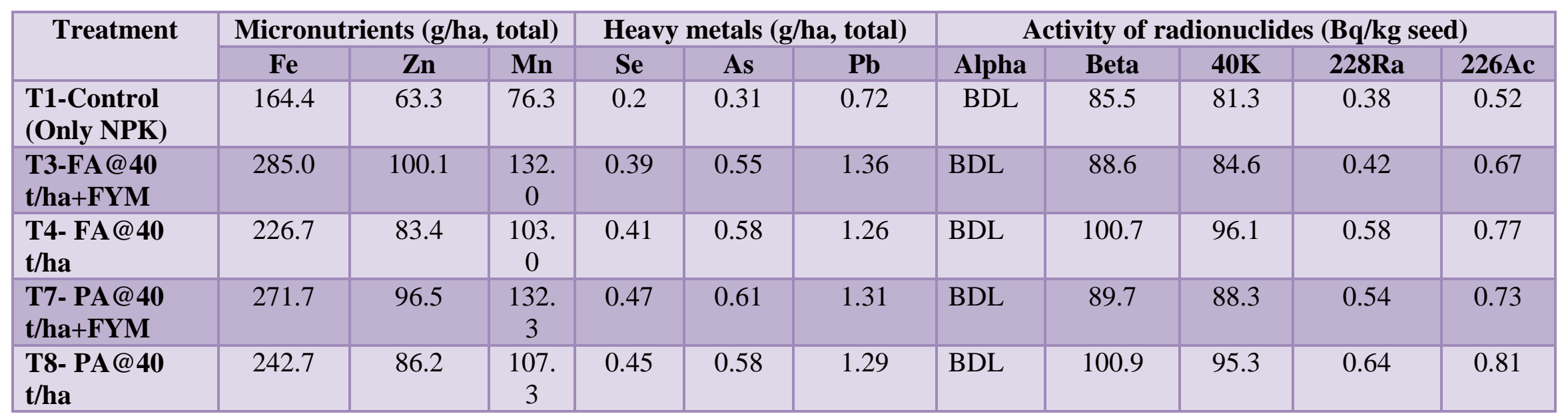

Table.5 Influence of application of FA and PA with and without FYM to sunflower on micronutrients, heavy metals and radio nuclides uptake by sunflower in black soil (two years average)

\begin{tabular}{|c|c|c|c|c|c|c|c|c|c|c|c|}
\hline \multirow[t]{2}{*}{ Treatment } & \multicolumn{3}{|c|}{ Micronutrients (g/ha, total) } & \multicolumn{3}{|c|}{$\begin{array}{c}\text { Heavy metals (g/ha, } \\
\text { total) }\end{array}$} & \multicolumn{5}{|c|}{ Activity of radionuclides (Bq/kg seed) } \\
\hline & $\mathbf{F e}$ & $\mathbf{Z n}$ & Mn & Se & As & $\mathbf{P b}$ & Alpha & Beta & $40 K$ & 228Ra & 226Ac \\
\hline T1-Control (Only NPK) & 187.4 & 104.6 & 106.8 & 0.31 & 0.38 & 1.00 & BDL & - & - & - & - \\
\hline T3-FA@40 t/ha+FYM & 318.4 & 154.0 & 179.2 & 0.58 & 0.68 & 1.61 & BDL & 90.6 & 89.2 & 0.52 & 0.74 \\
\hline T4-FA@40 t/ha & 314.3 & 139.4 & 139.3 & 0.53 & 0.65 & 1.63 & BDL & 103.1 & 98.1 & 0.62 & 0.78 \\
\hline T7-PA@40 t/ha+FYM & 302.4 & 153.5 & 169.8 & 0.52 & 0.68 & 1.61 & BDL & 94.0 & 94.9 & 0.65 & 0.80 \\
\hline T8-PA@40 t/ha & 300.8 & 141.6 & 164.5 & 0.55 & 0.66 & 1.52 & BDL & 104.2 & 97.3 & 0.64 & 0.93 \\
\hline
\end{tabular}


Table.6 Influence of application of FA and PA with and without FYM to groundnut on micronutrients, heavy metals and radio nuclides uptake by groundnut in Red soil during kharif (two years average)

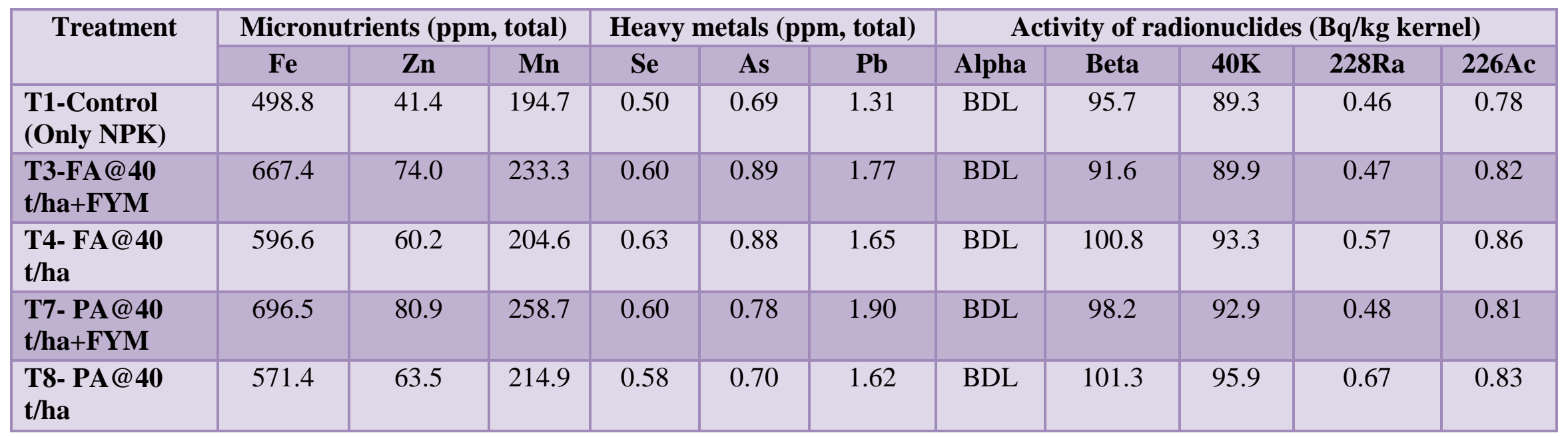

Table.7 Influence of application of FA and PA with and without FYM to maize on micronutrients, heavy metals and radio nuclides uptake by maize in black soil (two years average)

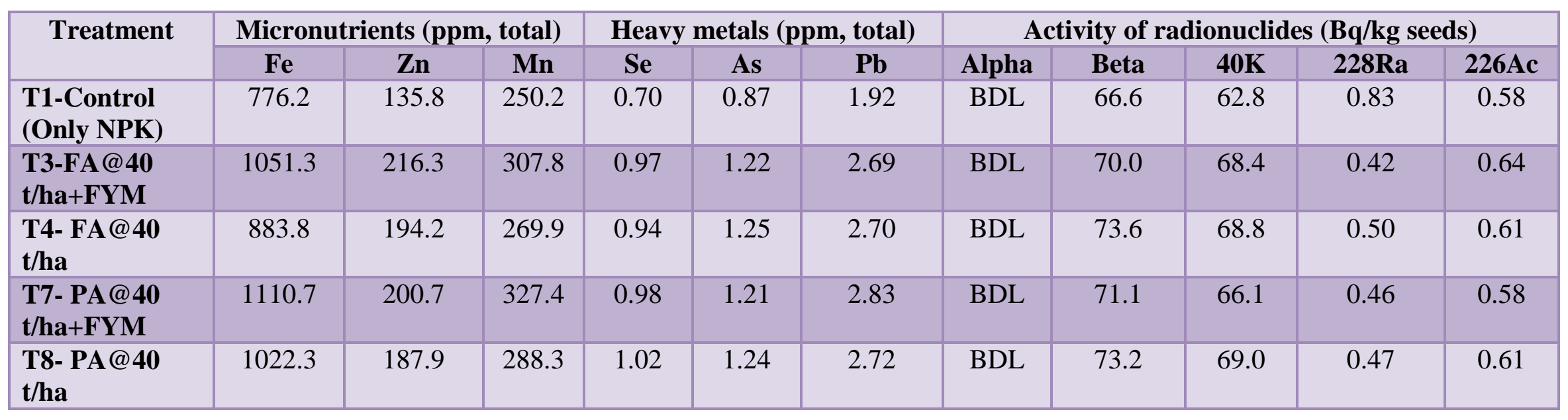




\section{No. of pods per plant in groundnut}

In case of groundnut grown on red soils the number of pods per plant was 10 in control which increased to 15 and 18 in FA and PA applied plots in red soil (Sao et al., 2007).

Head diameter in sunflower, shelling percentage in groundnut and cob length in maize

Application of ashes at the rate of $30 \mathrm{t} / \mathrm{ha}$ along with FYM in red soil resulted in significantly higher head diameter $(14 \mathrm{~cm})$ in sunflower, higher shelling percentage $(76 \%)$ in groundnut compared to control $(12 \mathrm{~cm}$ and $60 \%$, respectively), while in black soil the higher head diameter of sunflower was $15 \mathrm{~cm}$ and higher maize cob length was $17 \mathrm{~cm}$. This influence is clearly indicating the potentiality of use of ash. The head size, shelling percentage and cob length is directly proportional to the yield level in sunflower, groundnut and maize crops, respectively. So, one has to exploit application of fly ash or pond ash to increase the yield levels (Shukla and Mishra, 1986 and Yeldhalli, 2007).

\section{Test weight of seeds of all the three crops}

It was found that hundred seed weight of these crops was increased due to application of ashes along with FYM both in red soil and black soil. It was more pronounced in PA than in FA. In Sunflower grown on red soil, it was $41.5 \mathrm{~g}$ in control which increased to $47.4 \mathrm{~g}$ and $48.6 \mathrm{~g}$ due to FA and PA applied along with FYM, respectively. While in Sunflower grown on black soil, it was $41.9 \mathrm{~g}$ in control which increased to $48.5 \mathrm{~g}$ and $50.0 \mathrm{~g}$ due to FA and PA applied along with FYM, respectively. In ground nut (red soil) and maize (black soil), it was $238.8 \mathrm{~g}$ and $231.5 \mathrm{~g}$ in control which increased to $270.6 \mathrm{~g}$ and $238.7 \mathrm{~g}$ due to FA applied along with FYM, respectively. While in plots applied with PA along with FYM, ground nut (red soil) and maize (black soil), it increased to $293.6 \mathrm{~g}$ and $239.3 \mathrm{~g}$, respectively. The test weight is also directly proportional to the yield level in crops. So, the use of fly ash in crops has to be made compulsorily wherever it is available (Yeldhalli, 2007).

\section{Seed yield of Sunflower and maize and pod yield of groundnut crop}

The seed yield of sunflower, groundnut and maize was found to increase significantly due to application of ashes compared to control. It was $7.7 \mathrm{q} / \mathrm{ha}$ (sunflower, red soil), $8.8 \mathrm{q} / \mathrm{ha}$ (sunflower, black soil), $10.32 \mathrm{q} / \mathrm{ha}$ (groundnut, red soil) and $17.7 \mathrm{q} / \mathrm{ha}$ (maize, black soil) in control which increased to 10 q/ha (sunflower, red soil and black soil), 17 q/ha (groundnut, red soil) and 22 q/ha (maize, black soil) due to application of ashes along with FYM.

This is the combined effect of ash and FYM, however, if ashes used alone also give significant higher yields indicating the necessity of popularizing the need of application of FA or PA in different crops at the rate of $30 \mathrm{t} / \mathrm{ha}$ along with FYM but not at 40 t/ha (Shukla and Mishra, 1986 and Yaledhalli, 2007). The greater application of fly ash doses decreased the yield of crop due to pozzolonic effect of fly ash in soil which induced the poor aeration and compaction (Khan and Khan, 1996).

\section{Oil content in sunflower seeds and} groundnut seeds

Application of FA along with FYM to sunflower crop and groundnut crop in red soil had significant and higher influence on oil content, while application of PA along with FYM to sunflower crop in black soil had no significant and higher influence on oil content. In both the soils the effect is 
significant compared to control which may be attributed to sulphur content of the ashes (Sao et al., 2007).

There was not much variation in control and other treatments with respect to heavy metals and radionuclides uptake. Similar findings were also reported by Singh et al., (1997). Petruzzelli et al., (1986) have reported that heavy metal uptake by wheat seedling grown on fly ahs amended soils was with in the permissible limits. Minimizing the accumulation of toxic metals in plants below critical levels for human health is most important. The uptake of heavy metals and entry of radioactive material into the grains should be minimum.

Both FA and PA can be used as a potential nutrient supplement for obtaining higher yield in crops thereby solving the solid waste disposal problem to some extent. An ultimate goal would be to utilize FA and PA in soils having less $\mathrm{WHC} /$ marginal soils to such an extent as to achieve enhanced moisture holding without affecting the soil quality and minimizing the accumulation of toxic metals in plants below critical levels for human health. The uptake of heavy metals and entry of radioactive material into the grains is negligible.

\section{References}

Davison, R.L., D.F.S. Natusch, J.R. Wallace, 1974, Trace elements in fly ash: dependence of concentration on particle size. Environ Sci. Technol, 8:1107-1113

Kalra, N., H.C. Joshi, A. Chaudhary, R. Chaudhary and S.K. Sharma, 1997. Impact of fly ash incorporation in soil on germination of crops. Bioresour. Technol., 61: 39-41.

Khan, M. R. AND Khan, M., 1996, The effect of fly ash on plant growth and yield of tomato. Environment Pollution, 92:
105-111.

Manisha Basu, Manish Pande, P.B.S. Bhadoria, and S.C. Mahapatra, 2008, Potential fly-ash utilization in agriculture: A global review. In https://doi.org/10.1016/j.pnsc.2008.12.0 06

Martens, D.C., 1971, Availability of plant nutrients in flyash. Compos Sci, 12:1519

Natusch, D.F.S. and J.R. Wallace, 1974, Urban aerosol toxicity: The influence of particle size. Science. 186: 695-699.

Papastefanou, C., 2008, Radioactivity of coals and fly ashes. J Radioanal NuclChem, 275 (1): 29-35

Patil, C.V., S.S. Prakash, N.A. Yeledhalli and G.R. Rajkumar, 1999, Characterization of Fly ash for utilization in agriculture. Proceedings of National Seminar on Fly ash characterization and its geotechnical applications, held at IISc., Bangalore

Petruzzelli, C., L. Lubrano, S. Cervelli, 1986, Heavy metal uptake by wheat seedling grown on fly ahs amended soils. J Environ Qual, 8: 171-175

Sao, S., $\quad$ R. Gothalwal, L.K. Thetwarj, 2007, Effects of flyash and plant hormones treated soil on the increased protein and amino acid contents in the seeds of ground nut (Arachishypogaea). Asian J Chem, 19 (2): 1023-1026

Sarangi, P.K., D. Mahakur and P.C. Mishra, 2001. Soil biochemical activity and growth response of rice Oryzasativa in fly ash amended soil. Bioresour. Technol., 76: 199205.

Shukla K.N. and L.C. Mishra, 1986, Effect of flyash extract on growth and development of corn and soybean seedlings. Water Air Soil Pollut, 27: 155-167

Sikka, R. and B.D. Kansal, 1994, 
Characterization of thermal power plant flyash for agronomic purposes and to identify pollution hazards. Bioresour Technol, 50: 269-273

Singh, S.N., K. Kulshreshtha and K.J. Ahmad, 1997, Impact of fly ash soil amendment on seed germination, seedling growth and metal composition of Viciafaba L. Ecol. Eng., 9: 203-208.

Theis, T.L., and Wirth J.L., 1977, Sorptive behaviour of trace metals on flyash in aqueous systems. Environ Sci. Technol., 11: 1096-1100

Yeledhalli, N.A., S.S. Prakash, S.B. Gurumurthy and M.V. Ravi, 2007, Coal fly ash as modifier of physic-chemical and biological properties of soil. Karnataka Journal of Agricultural Sciences, 20 (3): 531-534.

\section{How to cite this article:}

Rajakumar, G.R. and Patil, S.V. 2019. Effect of Fly Ash on Growth and Yield of Crops with Special Emphasis on Heavy Metals and Radionuclide's. Int.J.Curr.Microbiol.App.Sci. 8(08): 127-137. doi: https://doi.org/10.20546/ijcmas.2019.808.016 